\title{
Öğrencilerin Uzaktan Eğitim Sistemine Bakış Açısı ve Uzaktan Eğitim İngilizce Dersinin Verimliliğinin Değerlendirilmesi: Banaz Meslek Yüksekokulu
}

\author{
Ahmet Erkan Metina ${ }^{\text {a* }}$ Abdurrahman Karaman ${ }^{\mathrm{b}}$, Yeşim Aksoy Şaştım \\ a,b,c Uşak Üniversitesi, Banaz Meslek Yüksekokulu, Uşak.
}

\section{$\ddot{O} z$}

Günümüzde iletişim ve teknoloji alanındaki hızlı gelişmeler yaşantımızın her alanında olduğu gibi eğitim, öğretim alanında da etkisini göstermektedir. Uzaktan Ĕ̆itim Sistemi, iletişim teknolojilerindeki hızlı gelişmelerden yararlanarak internet aracılığıyla mekândan ve zamandan bağımsız olarak derslerin öğrencilere sunulduğu bir eğitim sistemidir. Türkiye' de ön lisans ve lisans eğitimi veren pek çok üniversite artık temel eğitim derslerini Uzaktan Eğitim Sistemiyle öğrencilere sunmaktadır. Türkiye' de Ege Bölgesinde bulunan Uşak Üniversitesi Banaz Meslek Yüksekokulundaki öğrencilere bazı temel dersler Uzaktan Eğitim Sistemiyle verilmektedir. Yapılan bu çalışmada öğrencilerin Uzaktan Ĕ̆itim Sistemine bakış açılarının ve bu temel derslerden biri olan İngilizce dersinde öğrencilerin takip, memnuniyet ve başarn seviyelerinin belirlenmesi amaçlanmıştır. Bu amaçla dersi alan 216 öğrenci ile yüz yüze anket çalışması yapılmış ve elde edilen veriler SPSS Statistics 20.0 programında Korelasyon analizi yöntemi kullanılarak değerlendirilmiştir. Analiz sonucunda elde edilen bulgular ankete katılan öğrencilerin $\%$ 67' sinin uzaktan eğitim derslerini yüz yüze eğitim kadar verimli bulmadıklarım göstermiştir. Anketörlerin \% 65' $i$ İngilizce dersini uzaktan eğitim sistemiyle almak istemediklerini belirtmişlerdir. Ankete katılan 216 öğrenciden sadece \%27.3'ünün uzaktan eğitim İngilizce dersini kaldığı ev veya yurttan izleme imkanına sahip olduğu belirlenmiştir. İngilizce dersini haftalı ders programına göre düzenli bir şekilde takip eden öğrenci oranı ise sadece \%9,3 olmuştur. Uzaktan eğitim sisteminde dersin düzenli takip edilmesi ile işlenişşseklinin ilgi çekici ve zevkli bulunması arasında önemli pozitif yönde yüksek korelasyon olduğu $(r=0,614)$ belirlenmiştir. Aynı zamanda dersin düzenli takip edilmesi ile bu öğrencilerin dersteki başarı durumları arasında da önemli pozitif yüksek korelasyon $(r=0,710)$ olduğu tespit edilmiştir. Sonuç olarak öğrencilere kaldıkları yurt veya evde internet ortamını sağlanması ve derslerin öğrenci tarafindan düzenli olarak takip edilmesi halinde uzaktan eğitim sistemi ile eğitim verilmesinin verimli bir uygulama olacağı belirlenmiştir.

Anahtar Kelimeler: Uzaktan Eğitim Sistemi, İngilizce, Banaz MYO.

\section{Student Perspectives on Distance Education and the Assessment of the Efficiency of Distance Education English Courses: Banaz Vocational College}

\section{Abstract}

As it was in all aspect of our lives, rapid developments in communication technologies have significant impacts also in education and training activities. Distance education or distance learning is an education system independent of time and place in which communication technologies are used and courses are conducted through internet. There are several universities in Turkey offering associate and undergraduate degrees through distance education programs. Some basic courses at Banaz Vocational College of Usak University in Turkey are offered through distance learning program. In this study, student perspectives on distance education system were identified and follow up, satisfaction and success levels of students in English courses which were offered through distance education program were investigated. A questionnaire study was 
performed with 216 students taking the course and resultant data were subjected to statistical analyses with SPSS 20.0 software. Of the participant students, \% 67 indicated that distance education classes were not as efficient as face-to-face classes. About $65 \%$ of them indicated that they didn't want to take English courses through distance education system. Of 216 participant students, 27.3\% indicated that they had a chance to follow English courses of distance education system from their homes or dorms. The ratio of students regularly following English courses in accordance with weekly schedule was 9.3\%. There were significant positive correlations between regular follow up and interesting and amusing teaching fashion of the course $(r=0,614)$. There was also significant high correlation between regular follow up and success level of the students in this course $(r=0,710)$. It was concluded that distance education can be used as an efficient tool in teaching as long as students have an access to internet from home or dorms and they regularly follow the courses.

Keywords: Distance Education, English, Banaz Vocational College.

\section{Gíriş}

Bilişim teknolojilerinin gelişmesi ile birlikte bilgisayar ve internetin eğitim ve öğretim alanında kullanılması yaygınlaşmıştır (Akman, 2008). Teknoloji alanında gerçekleşen hızlı gelişmeler eğitim alanında da kendini göstermiş ve bireyin toplumsallaşma sürecinde etkili olan her faktörün dolayısıyla eğitimin de yeniden düzenlenmesini bir zorunluluk haline getirmiştir. Bu uygulamaların en önemlisi uzaktan eğitimdir (Ekici, 2003 ).

Uzaktan eğitim ilk şekli Avrupa'daki yazışma kurslarıyla gerçekleşti. Bu eğitim radyo ve televizyonun popüler hale geldiği yüzyılın ortalarına kadar kabul edilen bir normdu (Sherry, 1995). Uzaktan eğitim, iletişim teknolojisi ile eğitim teknolojisinin olanaklarını kullanarak kitlelere eğitim hizmeti götürmenin amaçlandığı çağdaş bir yaklaşımdır. Bu yaklaşımla geleneksel eğitimin yapısındaki katılık büyük ölçüde giderilerek, eğitime esneklik özelliği kazandırılmıştır. Uzaktan eğitim bir sistem olarak, kendine özgü özellikleriyle, öğretimin, bireylerin kendi buldukları bir çevrede ve bireysel öğrenme yeterliklerine uygun biçimde oluşmasını sağlayan bir yapıya sahiptir (Özer, 1990). Uzaktan eğitim, öğretmen ve öğrencinin aynı mekânlarda bulunmak zorunda olmadığı ve eğitim-öğretim faaliyetlerinin posta hizmetleri ve iletişim teknolojileri sayesinde yürütülen bir eğitim sistemi modelidir (İşman, 2011 ). Uzaktan eğitim, kısaca zaman ve mekândan bağımsız, bilişim teknolojilerinden yararlanarak gerçekleştirilen ekonomik ve etkileşimli bir eğitim biçimidir (Gökçe, 2008). Uzaktan eğitim, öğrenci ve öğretim elemanını sanal sınıf ortamından bağımsız olarak bir araya getirirken, zamandan bağımsız olarak da öğrenciye eğitim olanağı sunmaktadır (Türkoğlu, 2015). Uzaktan eğitim ile öğrenci - fakülte haberleşmesi, aktif öğrenme, ödevler üzerindeki zaman, öğrenciler arasındaki birliktelikler arttırılabilmekte, dönütlerin hemen alınması sağlanabilmekte, öğrenmenin yolları ve yetenekleri farklılaştırılabilmekte ve öğrencilerden daha yüksek beklenti elde edilebilmektedir (King, 2002).

Ruksakuk (1999)'a göre, genel olarak internet tabanlı uzaktan eğitim, gelişmiş teknolojik gereçlerle birbirinden uzak öğrenciler ve eğitim kadrosunun etkileşimli olarak veri alışverişinde bulunması şeklinde tanımlanabilir (Odabaş, 2003). 
Üniversiteler de teknolojik gelişimle beraber, modern insanın kendini yenileme ihtiyacına cevap vermede uzaktan eğitim sistemini kullanmaya başlamışlardır (Gökçe, 2008). Yurtdışında, internet tabanlı uzaktan eğitime yardımcı kaynak olarak Tv yayıncılığını kullanan bölümler de bulunmaktadır. Örneğin; Güney Carolina Üniversitesi Kütüphane Bilgi Bilimi Okulunda verilen bazı lisans dersleri Tv' de yayınlanarak internet tabanlı eğitim programları yürütülmektedir. (Anonim, 2002a). Pitssburgh Üniversitesi Bilgi Bilimi Okulunda da internet tabanlı uzaktan eğitim ile yüksek lisans, doktora ve sertifika programları düzenlenmektedir. (Anonim, 2012b). Ülkemizde uzaktan eğitim çalışmaları 1920 yıllara kadar gitmektedir. Bu yıllarda yalnızca fikir düzeyinde kalan uzaktan eğitimin ilk somut adımı 1950 yılında Ankara Üniversitesi Banka ve Ticaret Enstitüsü' nün girişimi ile atılmış bankacılık sektöründe çalışanlara mektupla eğitim verilmiştir. Sonraki yıllarda, çeşitli kurum ve kuruluşlar tarafından mektupla eğitim çalışmaları sürdürülmüştür. Özellikle Anadolu Üniversitesi tarafından sürdürülen posta ile eğitim programları başarılı örneklerden biri olarak gösterilebilir (Toptaş, 2001).

Örgün ve uzaktan eğitim uygulamaları incelendiğinde kullanılan teknolojilerin bu eğitimlere verdiği en temel özelliğin, öğrencilere zamandan ve mekândan bağımsızlık sağlayabilmesi olduğu görülebilir. Doğru yöntem ve uygun teknoloji kullanıldığı, öğrenci ve öğretmen arasındaki iletişim gerektiği şekilde sağlandı̆̆ 1 takdirde, internetle uzaktan eğitim uygulamalarının, örgün eğitim uygulamaları kadar başarılı olabileceği düşünülebilir (Yılmaz ve Horzum, 2005). Özellikle uzaktan eğitim sisteminden yararlanan öğrencilerin, eğitimini kendi kendine sürdürmek zorunda kalmaları, yalnızlık, uyumsuzluk, güdülenememe, iletişim ve etkileşim yetersizliği vb. pek çok sorunlarla karşılaştıkları göz önüne alınacak olursa, öğrenme sitillerinin uygun olarak düzenlenmesi pek çok yarar sağlayacaktır (Ekici, 2003).

$\mathrm{Bu}$ araştırmada, yükseköğretim kurumunda örgün öğretim ön lisans programında eğitim gören öğrencilerin Uzaktan Eğitim Sistemine bakış açıları ve bu sistemle yürütülen temel derslerden biri olan İngilizce dersinde öğrencilerin takip, memnuniyet ve başarı seviyelerinin belirlenmesi amaçlanmıştır. Bu amaçla Uşak Üniversitesi Banaz Meslek Yüksekokulunda Uzaktan Eğitim İngilizce dersini alan, tam sayım metodu ile belirlenen 216 öğrenci ile yüz yüze anket çalışması yapılmış ve elde edilen veriler SPSS Statistics 20.0 programında Korelasyon analiz yöntemi kullanılarak değerlendirilmiştir.

\section{MATERYAL VE YÖNTEM}

İngilizce derslerini uzaktan eğitim aracılı̆̆ıyla alan ön lisans seviyesindeki öğrencilerin başarılarının, dersin öğrenci üzerinde verimliliğinin ölçülmesi ve uzaktan eğitim sisteminin genel olarak değerlendirilmesi amacıyla yapılan bu çalışmada çalışma evreni olarak Uşak Üniversitesi Banaz Meslek Yüksek Okulu öğrencileri seçilmiştir. Bu kapsamda tesadüfi örnekleme stratejisi örneklem yöntemi olarak belirlenmiştir. Bu amaçla uzaktan eğitim derslerini alan, Ormancılık ve Orman Ürünleri Bölümünde öğrenim gören 100 öğrenci, Mimari ve Dekoratif Sanatlar Bölümünde öğrenim gören 86 öğrenci, Kimya Teknolojisi bölümünde öğrenim gören 
17 öğrenci ve Laboratuvar Teknolojisi Bölümünde öğrenim gören 13 öğrenci olmak üzere toplam 216 öğrenciyle yüz yüze anket çalışması yapılmıştır.

Veri toplama aracı olarak kullanılan anket formu 3 bölümden oluşmaktadır. Öğrencilere anket formunda toplam 20 adet soru sorulmuştur. İlk bölümde demografik durumu tespit etmeye yönelik 6 soru sorulmuştur. İkinci bölümde sorulan 4 soru öğrencilerin uzaktan eğitim sistemiyle derslerin işlenişine karşı bakışlarının olumlu ya da olumsuz olduğunu tespit etmeye yönelik olup, derslerini uzaktan eğitim sistemiyle alma isteklerinin belirlenmesine ve başarılarını ölçmeye yönelik hazırlanmıştır. Üçüncü bölümde bulunan 10 soru ise Uzaktan eğitim İngilizce dersinin işleniş şeklinin öğrenciler tarafından değerlendirilmesine ve derslere katılım durumlarının belirlenmesine yöneliktir.

Elde edilen anket verilerinin değerlendirilmesi için SPSS 20.0 istatistik paket programından yararlanılmıştır. Mevcut verilerin yapı geçerliliğini test edebilmek amacıyla güvenilirlik analizi yapılmıştır. Bunun sonucunda Croncbach Alpha değeri $0,84(0,70>\alpha>1)$ olduğu tespit edilmiştir. Katılımcı öğrencilerin tanımlayıcı istatistiki bilgilerine ulaşmak amacıyla frekans bilgileri ve yüzdeleri belirlenmiştir. Değişkenler arasında ilişkinin yönünü ve şiddetini belirleyebilmek amacıyla Korelasyon Analizi yapılmıştır. Bu bağlamda Frekans ve yüzde analizleri 0.05, korelasyon analizi 0,01 ve 0,05 güvenilirlik anlamlılık düzeyi ölçüt alınarak düşük, orta ve yüksek şiddette ilişkisi olan değişkenler incelenmiştir.

\section{BULGULAR}

Ankette Bulunan Uzaktan Eğitim Derslerine Öğrencilerin Genel Bakışlarının Belirlenmesine Yönelik Soruların Değerlendirilmesi

Katılımcılara "Uzaktan eğitim dersleri yüz yüze eğitim dersleri kadar önemlimidir ?" sorusuna cevaplarının oransal dağılımı Şekil 1'de verilmiştir

Şekil 1'e göre katılımcıların \%39' u bu soruya hiç katılmıyorum, \%18'i katılmıyorum, \%15'i katılıyorum, \%15' i kararsızım, \%11' i ise kesinlikle katılıyorum cevabını vermişlerdir.

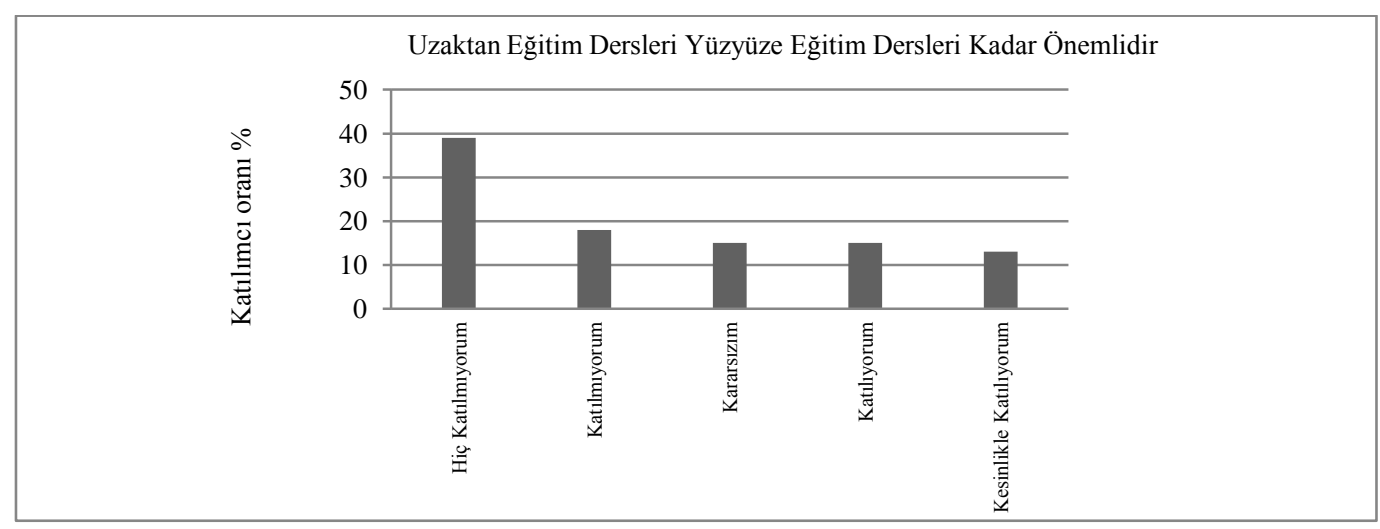

Şekil 1. "Uzaktan Eğitim Dersleri Yüz Yüze Eğitim Dersleri Kadar Önemlimidir?" Sorusuna Verilen Cevapların Katılımcı Sayısına Göre Oransal Dağılımı 
Öğrencilerin normal eğitime kıyasla uzaktan eğitim derslerinde daha başarılı olup olmadıklarını belirlemek için yönelttiğimiz soruya katılımcların sadece \%11' i (katılıyorum $=\% 7,4$, kesinlikle katılıyorum $=\% 3,6$ ) uzaktan eğitim derslerinde daha başarılı olduğunu belirtirken $\% 74,5^{\prime}$ i (hiç katılmıyorum $=\% 50,9$, katılmıyorum $=\% 23,6$ ) yüz yüze eğitimle verilen derslerde daha başarılı olduklarını belirtmişlerdir. Katılımcıların bu soruya verdikleri cevapların oransal dağılımı Şekil 2'de verilmiştir.

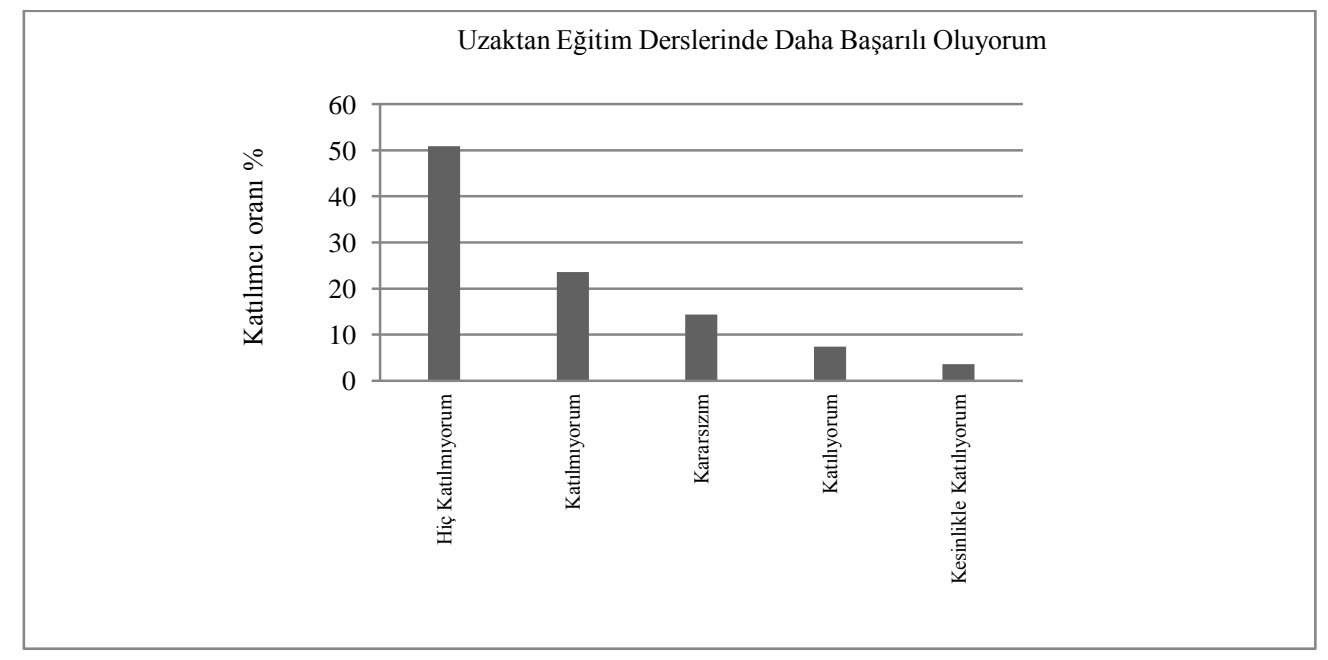

Şekil 2. "Uzaktan Eğitim Derslerinde Yüz Yüze Eğitim Derslerinden Daha Başarılı Oluyor Musunuz ?" Sorusuna Verilen Cevapların Katılımcı Sayısına Göre Oransal Dağılımı

Uzaktan eğitim derslerine katılım olanaklarının öğrenilmesi ile ilgili olan soruya anket katılımcilarının \% 27'si (katılıyorum= \%22,7, kesinlikle katıliyorum=\%4,3) kaldığı ev veya yurttan katılım imkânı olduğunu belirtirken, \%21' i katılıyorum= \%18, kesinlikle katılıyorum \%3) okulun laboratuvarından katılma imkânı olduğunu belirtmiştir. Şekil 3'te anket uygulanan öğrencilerin uzaktan eğitim derslerine kaldıkları ev veya yurttan katılma imkânlarına, Şekil 4'te okul laboratuvarından katılma olanaklarına ilişkin verdiği cevapların yüzdelik dağılımları verilmiştir.

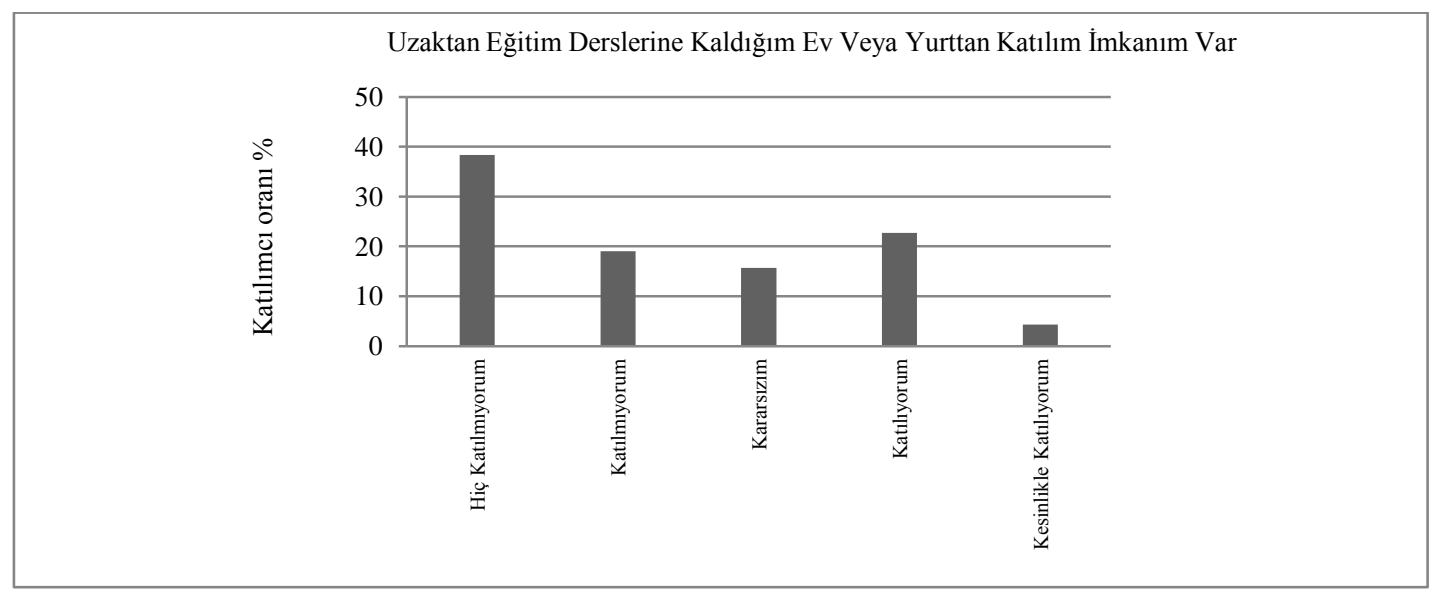

Şekil 3. "Uzaktan Eğitim Derslerine Kaldığınız Ev Veya Yurttan Katılım İmkanınız Varmı?" Sorusuna Verilen Cevapların Katılımcı Sayısına Göre Oransal Dağılımı 


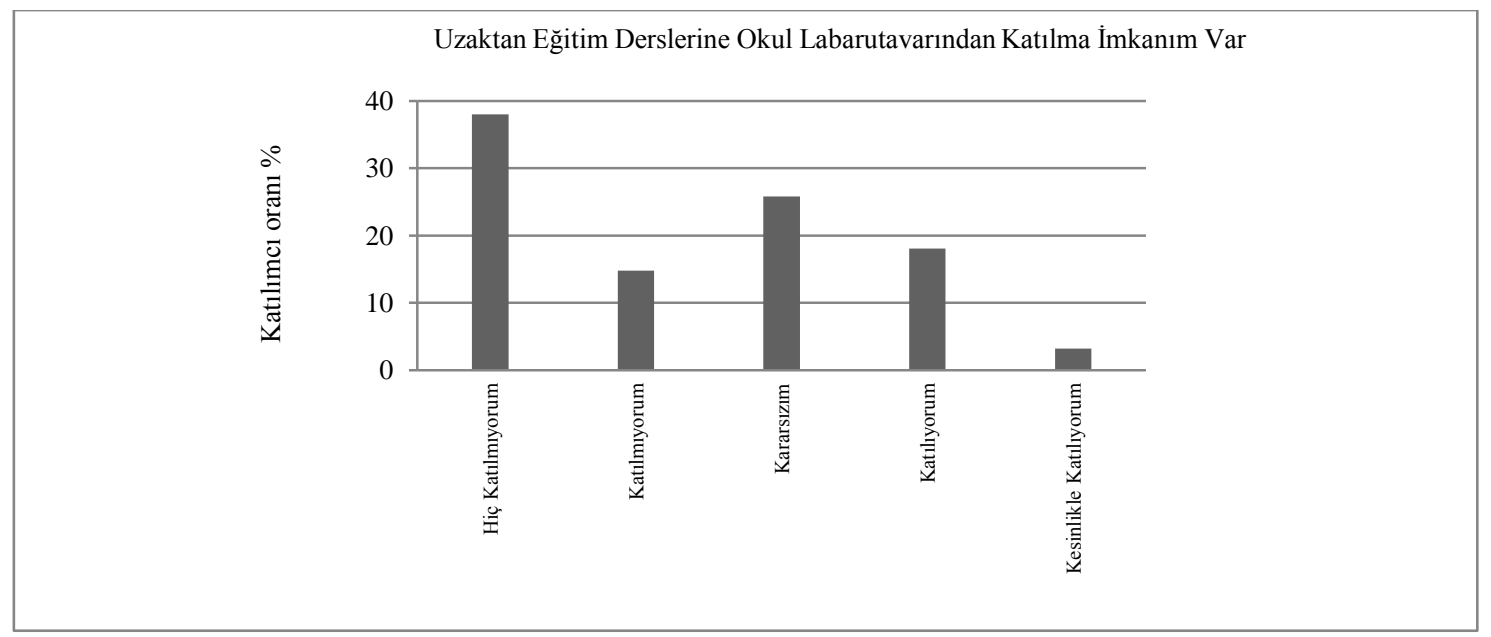

Şekil 4. "Uzaktan Eğitim Derslerine Okul Laboratuvarından Katılma İmkânınız Varmı?" Sorusuna Verilen Cevapların Katılımcı Sayısına Göre Oransal Dağılımı

Katılımcılara yöneltilen "Uzaktan eğitim dersleri yüz yüze eğitim derslerinde olduğu kadar verimli buluyor musunuz" sorusuna katılımcıların \%67,1'i (hiç katılmıyorum $=\% 47,2$, katılmıyorum $=\% 19,9$ ) verimli bulmadıklarının belirtmişlerdir. Katılımcıların bu soruya verdikleri cevapların oransal dağılımları Şekil 5 'te verilmiştir.

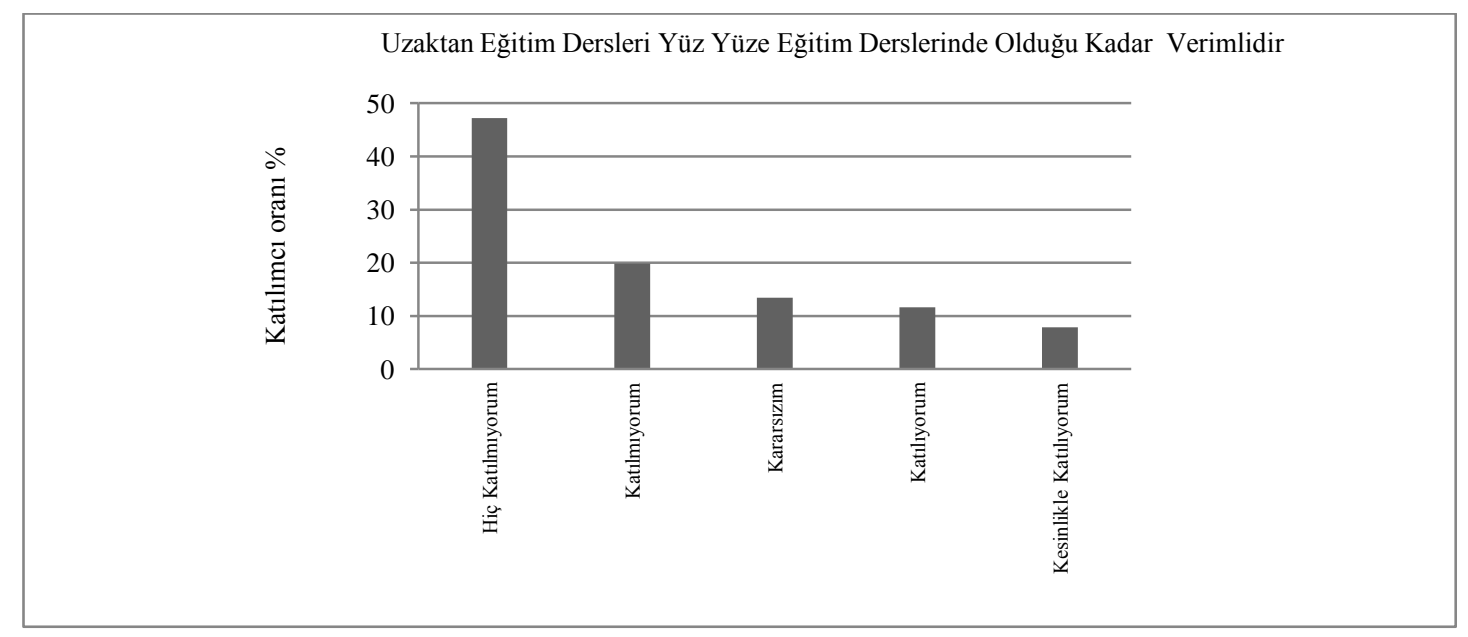

Şekil 5. "Uzaktan Eğitim Dersleri Yüz Yüze Eğitim Derslerinde Olduğu Kadar Verimli midir ?" Sorusuna Verilen Cevapların Katılımcı Sayısına Göre Oransal Dağılımı

Uzaktan eğitim sistemiyle verilen İngilizce dersinin işlenişini ilgi çekici ve zevkli bulan öğrencilerin oransal dağılımı Şekil 6'da verilmiştir. Katılımcıların \% 78,3' ü (hiç katılmıyorum=\%54,2, katılmıyorum=\%24,1) uzaktan eğitim İngilizce derslerinin işlenişini ilgi çekici ve zevkli bulmadıklarını belirtirken, katılımcıların sadece \%7,9'u (katılıyorum $=\% 6,9$, kesinlikle katılıyorum=\%1) derslerin işlenişini ilgi çekici ve zevkli bulduğunu belirtmiştir. 


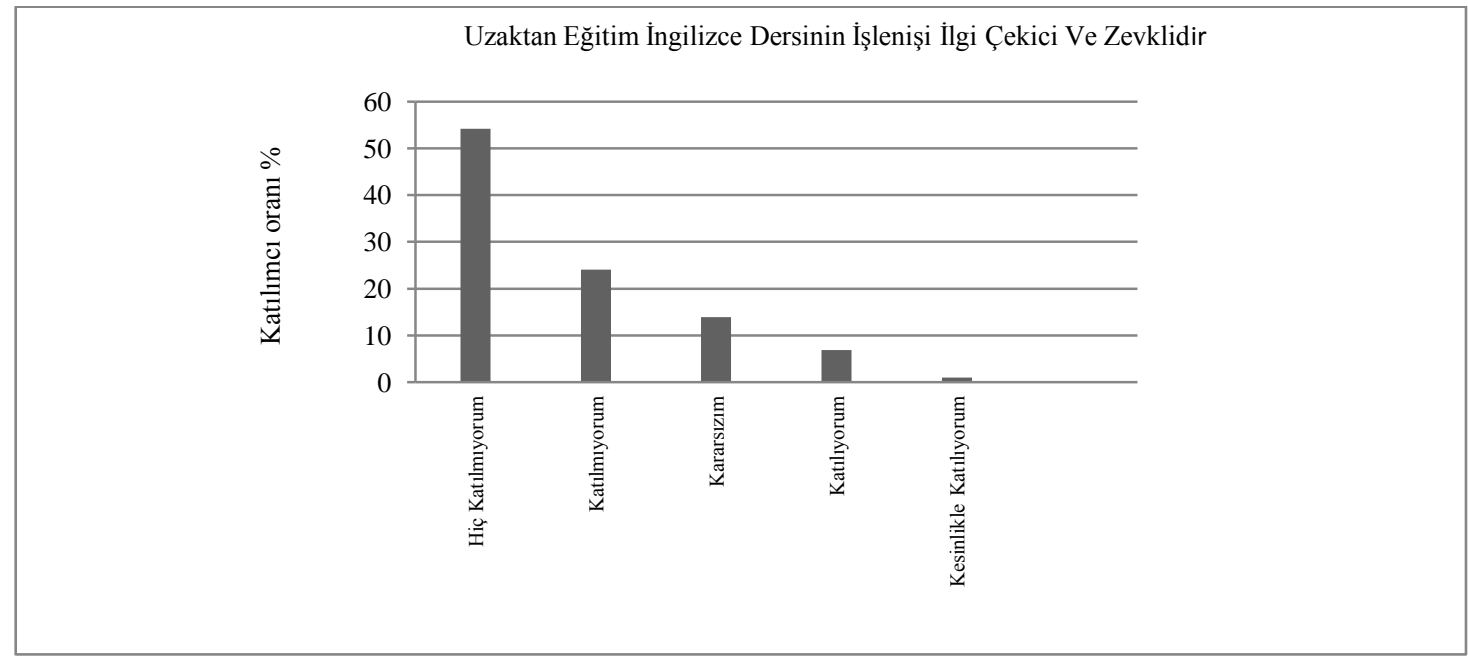

Şekil 6. "Uzaktan Eğitim İngilizce Dersinin İşlenişi İlgi Çekici Ve Zevklimidir?" Sorusuna Verilen Cevapların Katılımcı Sayısına Göre Oransal Dağılımı

Uzaktan eğitim İngilizce dersini sadece sınava yakın bir zamanda toplu olarak izleyerek çalışan öğrencilerin oransal dağılımı Şekil 7'de verilmiştir. Verilere göre öğrencilerin \%14,8'i (katılıyorum= \%10,2, kesinlikle katılıyorum= \%4,6) uzaktan eğitim sinavlarına sadece sinava yakın bir zamanda toplu olarak izleyerek hazırlanmaktadırlar.

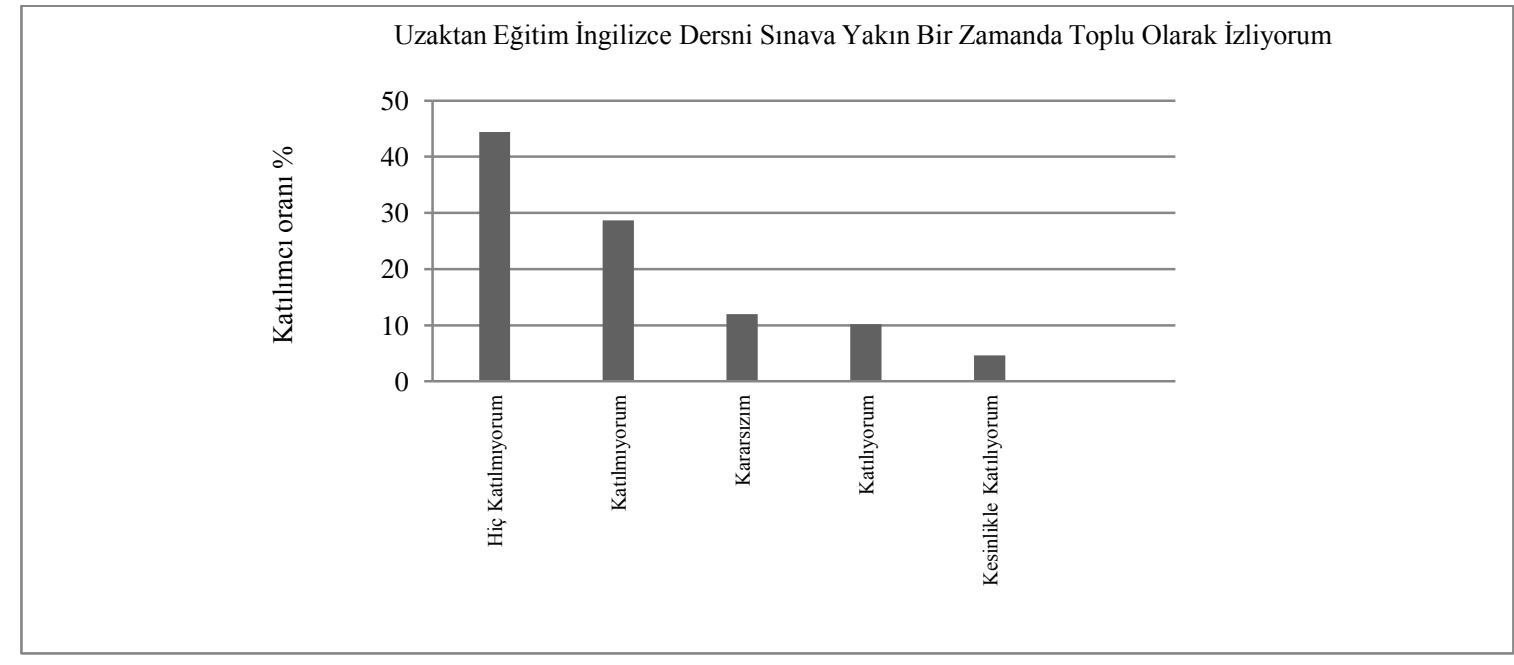

Şekil 7. "Uzaktan Eğitim İngilizce Dersini Sınava Yakın Bir Zamanda Toplu Olarak İzliyorum " Sorusuna Verilen Cevapların Katılımcı Sayısına Göre Oransal Dağılımı

Uzaktan eğitim derslerini izlemeyip sınava sadece geçmiş yılların soruları üzerinden çalışan öğrencilerin oransal dağılımı Şekil 8' de verilmiştir. Verilere göre öğrencilerin \%54,1'i (katıllyorum= \%34,7, kesinlikle katılıyorum=\%19,4) uzaktan eğitim sınavlarına sadece geçmiş yılların sorularını çözerek hazırlanmaktadırlar. 


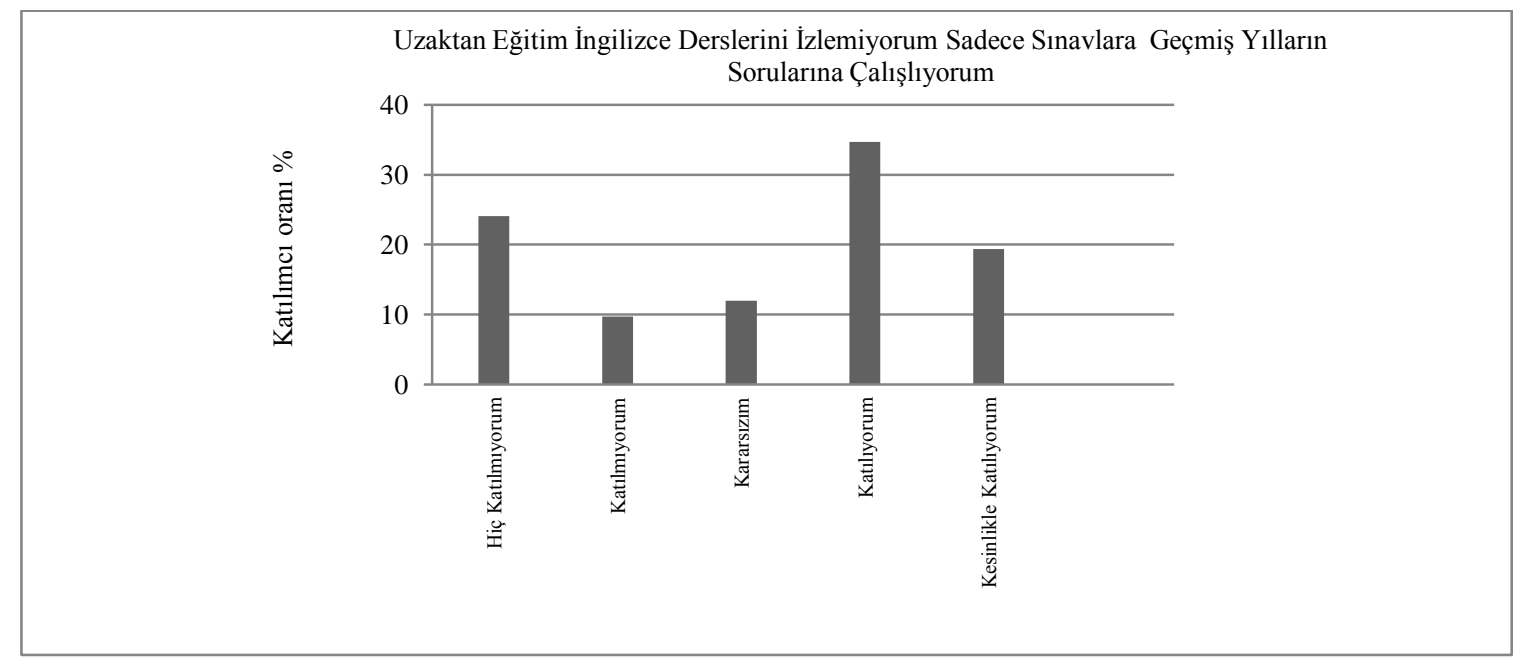

Şekil 8. "Uzaktan Eğitim İngilizce Derslerini İzlemiyor Sadece Sınavlara Geçmiş Yılların Sorularına mı Çalışıyorsunuz?" Sorusuna Verilen Cevapların Katılımcı Sayısına Göre Oransal Dağılımı

Öğrencilerin kendi kendilerine çalışma alışkanlıkları olduğunu belirleyebilmek için yöneltilen soruya öğrencilerin \%39,8'i (hiç katılmıyorum= \%25, katılmıyorum= $\% 14,8)$ kendi kendime çalışma alışkanlıklarının olmadığını belirtirken, \%43,5'i (katılıyorum $=\% 27,8$, kesinlikle katıliyorum $=\% 15,7)$ kendi kendine çalışma alışkanlığının olduğunu belirtmiştir. Öğrencilerin kendi kendine çalışma alışkanlıklarını olup olmadığını tespit etmek için yönelttiğimiz soruya verilen cevapların oransal dağılımı Şekil 9'da verilmiştir.

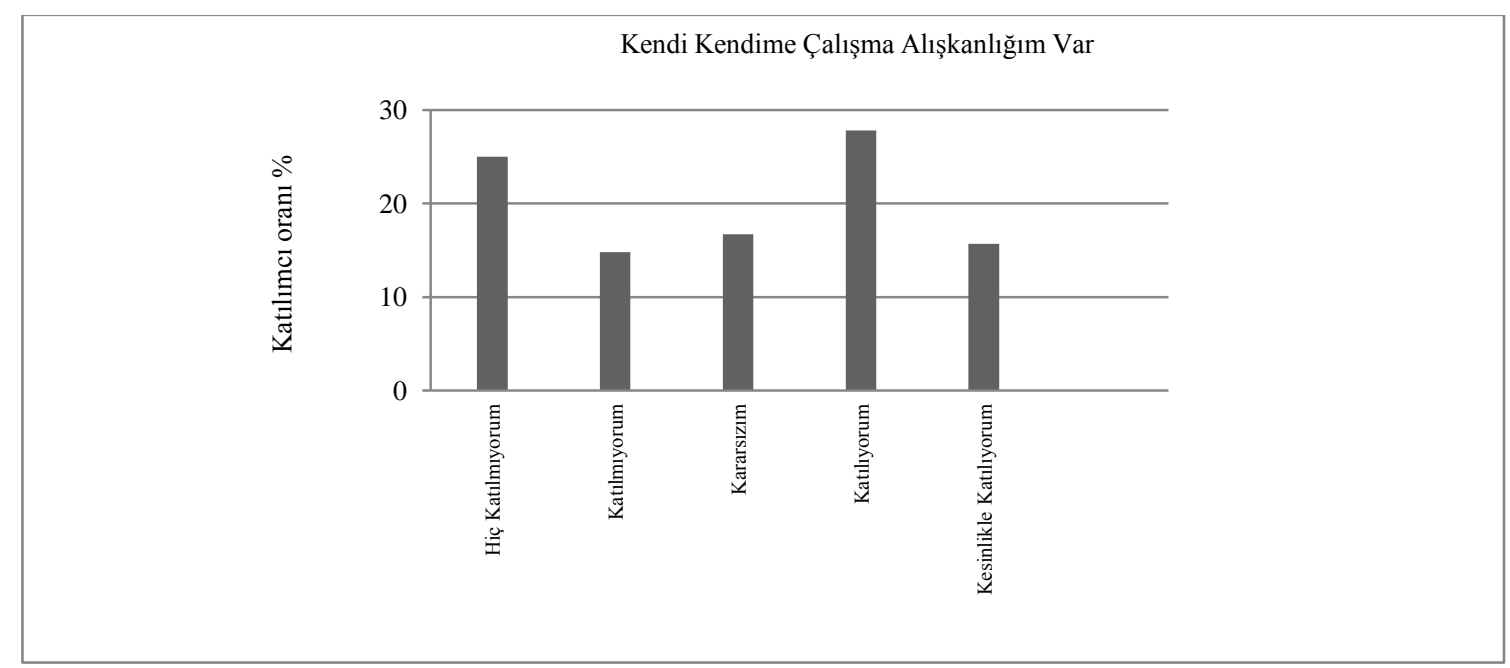

Şekil 9. "Kendi kendinize çalışma alışkanlığınız varmı?" sorusuna verilen cevapların katılımcı sayısına göre oransal dağılımı

\section{Uzaktan Eğitim Sistemiyle Yürütülen İngilizce Dersine Öğrenci Yaklaşımlarının Belirlenmesine Yönelik Soruların Değerlendirilmesi}

Korelasyon analizi sonuçlarına göre uzaktan eğitim sisteminde İngilizce dersinin programına göre düzenli takip edilmesi ile işlenişs şeklinin ilgi çekici ve zevkli 
bulunması faktörleri arasında 0,001 seviyesinde pozitif yönlü ve yüksek şiddette $(\mathrm{r}=0,617)$ anlamlı bir ilişki olduğu ve dersi programına göre düzenli olarak takip eden öğrencilerle başarılı olmaları arasında da $(r=710)$ yüksek şiddette pozitif yönlü bir ilişki olduğu belirlenmiştir.

Uzaktan eğitim sisteminde İngilizce dersini sadece sınavlara yakın bir zamanda toplu olarak izleyen öğrencilerin, dersin işleniş şeklinin ilgi çekici ve zevkli bulunması faktörleri arasında 0,001 seviyesinde pozitif yönlü ve düşük şiddette $(r=0,328)$ anlamlı bir ilişki olduğu ve uzaktan eğitim İngilizce dersini programına göre düzenli olarak takip eden öğrencilerle başarılı olmaları arasında da $(r=249)$ düşük şiddette pozitif yönlü bir ilişki olduğu gözlemlenmiştir. Faktör analizi sonucunda elde edilen boyutların ne yönde etkilediklerini açıklayan korelasyon analizi sonuçları Tablo 1'de verilmiştir.

Tablo 1. Uzaktan Eğitim İngilizce Dersini programına göre Düzenli Takip eden Öğrenciler ve Uzaktan Eğitim İngilizce Dersini Sadece Sınavlara Yakın Bir Zamanda Toplu Olarak İzleyen Öğrencilerin Dersin İşlenişini İlgi Çekici ve Zevkli Bulmaları ve Başarı Durumları Arasındaki İlişkinin İncelenmesi

\begin{tabular}{|c|c|c|c|c|}
\hline & & \\
\hline & & & $\begin{array}{l}\text { Uzaktan Eğitim } \\
\text { İngilizce Dersinin } \\
\text { İşlenişi ilgi Çekici } \\
\text { ve Zevklidir }\end{array}$ & $\begin{array}{l}\text { Uzaktan Eğitim } \\
\text { İngilizce } \\
\text { Dersinde } \\
\text { Başarılı } \\
\text { Oluyorum }\end{array}$ \\
\hline \multirow{3}{*}{$\begin{array}{l}\text { Pearson } \\
\text { Korelasyon }\end{array}$} & $\begin{array}{l}\text { Uzaktan Eğitim İngilizce } \\
\text { Dersini Programına Göre } \\
\text { Takip Ediyorum }\end{array}$ & $\begin{array}{l}\text { Korelasyon } \\
\text { Katsayis1 }\end{array}$ & $617^{*}$ &, $710^{*}$ \\
\hline & \multirow{2}{*}{$\begin{array}{l}\text { Uzaktan Eğitim İngilizce } \\
\text { Dersini Sınava Yakın Bir } \\
\text { Zamanda Toplu Olarak } \\
\text { İzliyorum }\end{array}$} & &, $328^{*}$ & $249^{*}$ \\
\hline & & Anlamlılık & 000 & ,000 \\
\hline
\end{tabular}

Uzaktan eğitim İngilizce dersini programına göre takip eden öğrencilerin dersi verimli bulmaları arasında 0,001 seviyesinde pozitif yönlü ve orta şiddette $(r=0,415)$ anlamlı bir ilişki olduğu gözlemlenirken, dersleri sadece sınava yakın bir zamanda toplu olarak izleyen öğrencilerin dersi verimli bulmaları arasında düşük şiddette (r=327) anlamlı bir ilişki gözlemlenmiştir. Faktör analizi sonucunda elde edilen boyutların ne yönde etkilediklerini açıklayan ilgileşim analizi sonuçları Tablo 2'de verilmiştir. 
Tablo 2. Uzaktan Eğitim İngilizce Dersini Düzenli Takip Eden Öğrencilerle Dersi Sınava Yakın Bir Zamanda Toplu Olarak İzleyen Öğrencilerin Dersi Verimli Bulmaları Arasındaki İlişki

\begin{tabular}{|c|c|c|c|c|}
\hline & & & $\begin{array}{l}\text { Uzaktan Eğitim } \\
\text { İngilizce Dersini } \\
\text { Programına } \\
\text { Göre Takip } \\
\text { Ediyorum }\end{array}$ & 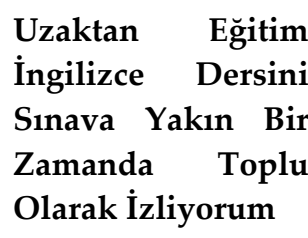 \\
\hline \multirow{2}{*}{$\begin{array}{l}\text { Pearson } \\
\text { Korelasyon }\end{array}$} & \multirow{2}{*}{$\begin{array}{lr}\text { Uzaktan } & \text { Eğitim } \\
\text { İngilizce } & \text { Dersi } \\
\text { Verimli Olmaktadır }\end{array}$} & $\begin{array}{l}\text { Korelasyon } \\
\text { Katsayısı }\end{array}$ &, $415^{*}$ & $327^{*}$ \\
\hline & & Anlamlılık & , 000 & ,000 \\
\hline \multicolumn{4}{|c|}{ * Korelasyon 0,01 düzeyinde anlamlıdır. } & \\
\hline
\end{tabular}

Uzaktan eğitim İngilizce dersinin işlenişini ilgi çekici ve zevkli bulan öğrencilerin uzaktan eğitim İngilizce dersini yüz yüze eğitim kadar verimli bulmaları arasında $(r=0,809)$ ve uzaktan eğitim İngilizce dersinde yüz yüze eğitim derslerinden daha başarılı olmaları arasında $(r=0,710) \quad 0,001$ seviyesinde pozitif yönlü yüksek şiddette anlamlı bir ilişki gözlemlenmiştir. Korelasyon analizi sonuçları Tablo 3 'te verilmiştir

Tablo 3. Uzaktan Eğitim İngilizce Dersini İlgi Çekici ve Zevkli Bulan Öğrencilerin Uzaktan Eğitim İngilizce Dersini Verimli Bulmaları Arasında ve Uzaktan Eğitim İngilizce Dersinde Başarılı Olmaları Arasındaki İlişki

\begin{tabular}{|c|c|c|c|c|}
\hline & & & $\begin{array}{lr}\text { Uzaktan } & \text { Eğitim } \\
\text { İngilizce } & \text { Dersi Yüz } \\
\text { Yüze } & \text { Eğitim } \\
\text { Dersleri } & \text { Kadar } \\
\text { Verimli } & \end{array}$ & $\begin{array}{l}\text { Uzaktan } \\
\text { İngilizce Dersinde } \\
\text { Yüz Yüze Eğitim } \\
\text { Derslerinden Daha } \\
\text { Başarılı Oluyorum }\end{array}$ \\
\hline \multirow{2}{*}{$\begin{array}{l}\text { Pearson } \\
\text { Korelasyon }\end{array}$} & \multirow{2}{*}{$\begin{array}{lr}\text { Uzaktan } & \text { Eğitim } \\
\text { İngilizce } & \text { Dersi İlgi } \\
\text { Çekici } & \text { Ve } \\
\text { Zevklidir } & \end{array}$} & $\begin{array}{l}\text { Korelasyon } \\
\text { Katsayis1 }\end{array}$ &, $809^{*}$ &, $710^{*}$ \\
\hline & & Anlamlılık & ,000 & ,000 \\
\hline
\end{tabular}

Uzaktan eğitim İngilizce dersine kaldığı ev veya yurttan katılma imkanı olan anket katılımcılarıyla uzaktan eğitim İngilizce dersinde yüz yüze eğitim derslerinden daha başarılı olmaları arasında $(r=0,320)$, ve uzaktan eğitim derslerini ilgi çekici ve zevkli bulmaları arasında $(r=0,384)$ 0,001 seviyesinde pozitif yönlü orta şiddette anlamlı bir ilişki gözlemlenmiştir. Korelasyon analizi sonuçları Tablo 4 'te verilmiştir. 
Tablo 4. Uzaktan Eğitim İngilizce Dersine Kaldığı Ev Ya Da Yurttan Katılma İmkânı Olan Öğrencilerin Dersi İlgi Çekici Ve Zevkli Bulmaları ve Yüz Yüze Eğitim Derslerinden Başarılı Olmaları Arasındaki İlişki.

\begin{tabular}{|c|c|c|c|c|}
\hline & & & $\begin{array}{l}\text { Uzaktan Eğitim } \\
\text { İngilizce Dersi İlgi } \\
\text { Çekici Ve } \\
\text { Zevklidir }\end{array}$ & $\begin{array}{l}\text { Uzaktan } \\
\text { İngilizce Dersinde } \\
\text { Yüz Yüze Eğitim } \\
\text { Derslerinden Daha } \\
\text { Başarılı Oluyorum }\end{array}$ \\
\hline \multirow{2}{*}{$\begin{array}{l}\text { Pearson } \\
\text { Korelasyon }\end{array}$} & \multirow{2}{*}{$\begin{array}{l}\text { Kaldığım Ev ya da } \\
\text { Yurtta Uzaktan } \\
\text { Eğitim İngilizce } \\
\text { Dersine Katılma } \\
\text { İmkanım Var }\end{array}$} & $\begin{array}{l}\text { Korelasyon } \\
\text { Katsayisı }\end{array}$ &, $384^{*}$ &, $320^{*}$ \\
\hline & & Anlamlılık & ,000 & ,000 \\
\hline${ }^{*}$ Korelasyc & 01 düzeyinde anla & & & \\
\hline
\end{tabular}

\section{SONUÇLAR}

Uşak Üniversitesi Banaz Meslek Yüksek Okulunda uzaktan eğitim sisteminin genel olarak değerlendirilmesi ve İngilizce derslerini uzaktan eğitim aracılığıyla alan ön lisans seviyesindeki öğrencilerin başarılarının ve dersin öğrenci üzerinde verimliliğinin ölçülmesi amacıyla yapılan bu çalışmada, araştırma konusu ile ilgili sorunlar ortaya konularak çözüm önerileri sunulmaya çalışılmıştır.

Sonuç olarak uzaktan eğitim derslerini sanal bir ortamda alan öğrencilerin \%57 si bu dersleri yüz yüze işlenen dersler kadar önemli görmediklerini, \%67' si uzaktan eğitim derslerini verimli bulmadıklarını, \%78' i derslerin işlenişini ilgi çekici ve zevkli bulmadıklarını, \%75' i yüz yüze verilen derslerde daha başarılı olduklarını belirtmişlerdir. Anket katılımcılarının \%54' ü uzaktan eğitim sınavlarına sadece geçmiş yılların sorularını çözerek sınavlara hazırlanırken, derslerin tamamını sadece sınava yakın bir zamanda izleyen öğrencilerin oranı \%14 olduğu görülmüştür.

Yaptığımız Korelasyon analizi sonuçlarına göre uzaktan eğitim İngilizce dersini düzenli olarak takip eden öğrencilerin uzaktan eğitim İngilizce dersinde yüz yüze eğitim derslerinden daha başarılı olmaları arasında $(\mathrm{r}=, 710)$ pozitif yönde yüksek şiddette bir ilişki olduğu görülürken, uzaktan eğitim İngilizce dersini sınava yakın bir zamanda toplu olarak izleyen öğrencilerin yüze eğitim derslerinden daha başarılı olmaları arasında $(r=, 249)$ düşük şiddette bir ilişki olduğu tespit edilmiştir. Uzaktan eğitim İngilizce dersini programına göre takip eden öğrencilerle dersi ilgi çekici ve zevkli bulmaları arasında $(r=, 617)$ pozitif yönlü bir ilişki olduğu tespit edilirken, uzaktan eğitim İngilizce dersini sadece sınava yakın bir zamanda toplu olarak izleyen öğrencilerde bu ilişkinin $(\mathrm{r}=, 328)$ düşük şiddette olduğu belirlenmiştir.

Uzaktan eğitim İngilizce dersinin verimliğinin dersin programına göre düzenli olarak takip edilmesiyle ilişkisinin belirlenmesine yönelik sorumuza aldığımız 
cevaplar neticesinde, dersi programına göre takip eden öğrencilerin dersi verimli bulmaları arasındaki ilişki $(r=415)$ orta şiddette olurken, dersi sınava yakın bir zamanda toplu olarak izleyen öğrencilerde bu ilişkinin $(r=, 327)$ düşük şiddette olduğu tespit edilmiştir. Uzaktan eğitim İngilizce dersinin işlenişini ilgi çekici ve zevkli bulan öğrencilerin uzaktan eğitim İngilizce dersini yüz yüze dersler kadar verimli bulmaları arasında $(\mathrm{r}=, 809)$ ve yüz yüze eğitim gördükleri derslerinden daha başarılı olmaları arasında $(\mathrm{r}=, 710)$ pozitif yönde yüksek şiddette bir ilişki olduğu görülmüştür. Uzaktan eğitim İngilizce dersine kaldığı ev veya yurttan katılma imkanı olan öğrencilerle dersin ilgi çekici ve zevki bulunması arasında(r=384) ve uzaktan eğitim İngilizce dersinde yüz yüze derslerden daha başarılı olmaları arasında ( $r=320)$ pozitif yönde orta şiddette bir ilişki olduğu görülmüştür.

Temel eğitimden itibaren sorunlu bir eğitim alanının oluşturan dil eğitimindeki mevcut durumun yükseköğretimde de devam ettiği görülmektedir. Anket sorularının değerlendirilmesi ile elde edilen veriler ve gözlemler sonucunda ortaya çıan sonuçlar dil eğitiminin uzaktan eğitim olarak bilgisayar ortamında verilmesinin dersin verimliliğini, ilgi çekiciliğini ve en önemlisi öğrencilerin başarısını etkilediği gözlemlenmiştir. Bu nedenle dil eğitimi derslerinin yüz yüze eğitim olarak hoca öğrenci arasında interaktif etkileşimli yapılmasıyla başarının arttırılabileceği öngörülmektedir. Bununla birlikte öğrencilerin uzaktan eğitim derslerini takip edebilmesinde temel faktör olan bilgisayar ve internete erişim imkânlarının öğrencilerin bulunduğu ev, yurt, okul gibi her ortamda sağlanabilmesi, öğrencilerin dersleri düzenli bir şekilde takip edebilmesine teşvik edici olacağından uzaktan eğitim derslerinde başarıyı arttıracak bir uygulama olarak görülmektedir.

\section{KAYNAKÇA}

Anonim, (2002a). http:/www.libsci.sc.edu/DE.html "Distance education on campus and distance students". School of Library Information Science. University of South Caroline.

Anonim, (2002b). http://www.tele.pitt.edu "Telecomminication program" School of Information Science. University of Pittsburgh.

Akman, E. ve Güler, E.İ. (2008). Biyomedikal Mühendisliğinde Uzaktan Eğitim Çalışmaları. Gazi Üniversitesi, Türkiye Bilişim Teknolojileri Dergisi, Cilt: 1/2, Ankara.

Ekici, G. (2008). Uzaktan Eğitim Ortamlarının Seçiminde Öğrencilerin Öğrenme Stillerinin Önemi, Hacettepe Üniversitesi Eğitim Fakültesi Dergisi, 24: 48-55.

Gökçe, T.A. (2008). Küreselleşme Sürecinde Uzaktan Eğitim, Dumlupınar Üniversitesi Eğitim Fakültesi Dergisi, 11; 1-12.

İşman, A. (2011). Uzaktan Eğitim. Pegem Akademi, 4. Baskı, ISBN 978-975-8792-82-2 Ankara.

King, W. J. (2002). Seven Principles of Good Teaching Practice.http://www.agron.iastate.edu/nciss/kingsat2.html.

Odabaş, H. (2003). İnternet Tabanlı Uzaktan Eğitim ve Bilgi ve Belge Yönetim Bölümleri. Türk Kütüphaneciliği, (17), 22-36.

Özer, B. (1990). Uzaktan Eğitim Sisteminin Evrensel Yapısı, Doğu Akdeniz Üniversitesi Kurgu Dergisi, 8: 569-594. 
Sherry, 1. (1995). "Issues in Distance Learning" International JI. Of educational Telecommunications (1995) 1(4), 337-365

Türkoğlu, T. (2015). Meslek Yüksekokulunda Örgün Öğretim Programındaki Öğrencilerin Uzaktan Öğretim Dersine Karşı Yaklaşımları. 4th International Vocational Schools Symposium, Yalova, 55-64.

Toptaş, E. (2001). "Uzaktan Eğitim ve Kütüphanecilik Bölümlerinde Uygulanması" Ankara Üniversitesi Dil ve Tarih - Coğrafya Fakültesi Kütüphanecilik Bölümü için Bir Model (Yayınlanmamış Yüksek lisans Tezi) Ankara

Yılmaz, K. ve Horzum, B.M. (2005). Küreselleşme, Bilgi Teknolojileri Ve Üniversite. İnönü Üniversitesi Ĕ̆itim Fakültesi Dergisi, 6 (10): 103- 121. 